2008

\title{
The Model Rules of Professional Conduct and Serving the Non-Legal Needs of Clients: Professional Regulation in a Time of Change
}

Robert Rubinson

University of Baltimore School of Law, rrubinson@ubalt.edu

Follow this and additional works at: http://scholarworks.law.ubalt.edu/all_fac

Part of the Legal Ethics and Professional Responsibility Commons, and the Legal Profession Commons

\section{Recommended Citation}

The Model Rules of Professional Conduct and Serving the Non-Legal Needs of Clients: Professional Regulation in a Time of Change, 2008 J. Prof. Law 119 (2008)

This Article is brought to you for free and open access by the Faculty Scholarship at ScholarWorks@University of Baltimore School of Law. It has been accepted for inclusion in All Faculty Scholarship by an authorized administrator of ScholarWorks@University of Baltimore School of Law. For more information, please contact snolan@ubalt.edu. 


\title{
The Model Rules of Professional Conduct and Serving the Non-Legal Needs of Clients: Professional Regulation in a Time of Change
}

\author{
Robert Rubinson*
}

\section{Introduction}

The practice of law is changing. Lawyers who act solely as advocates and zealous representatives of clients in legal matters still represent the core of what lawyers do and of how many lawyers see their work, but other trends are filtering into "on the ground" practice. Increasing numbers of lawyers are mediating, consulting on traditionally non-legal issues, and approaching clients' needs "holistically" by associating with and integrating other professional services. ' These trends cut across virtually all segments of the profession, from prosecutors and criminal defense lawyers, to lawyers whose practices involve, among other things, public interest work, personal injury, family law, and business law. All indicationssociological, legal, and economic-suggest that these transformations of what lawyers do will continue.

The purpose of this Article is to offer a bird's eye view of an evolving profession, a kind of "Practice 2000" examination of where the profession has been and where it appears to be going. The goal is not to examine in depth individual movements and practices and the specific ethics issues implicated by each-as noted below, scholars and practitioners have done this already in many instances ${ }^{2}$ - but rather to survey the terrain and note linkages and connections among seemingly discrete practices performed in widely disparate practice areas. In this regard, a key thesis of this Article is that these trends interlock and represent shifts in what it means to be a lawyer.

The Article will approach this topic at a number of levels. It will first address the traditional notions of practice undergirding the Model Rules of Professional

*Professor of Law and Director of Clinical Education, University of Baltimore School of Law. I would like to thank the American Bar Association, and especially Arthur Garwin, for commissioning and supporting the writing of this Article. I am also indebted to Avis Buchanan, Robert Keatinge and Mark Scurti-my fellow panelists at the ABA National Conference on Professional Responsibility—and Arthur J. Lachman - a member of the ABA Center for Professional Responsibility National Conference Planning Committee-for sharing their insights and experiences.

1. This differs from the issue of whether lawyers should formally associate with other professionals in "multidisciplinary practices." For an overview of the MDP debate, see Dennis J. Block et al., Model Rule of Professional Conduct 5.7: Its Origin and Interpretation, 5 Geo. J. LeGaL ETHICS 739, 764-777 (1992).

2. See infra text accompanying notes $70-73$. 
Conduct and, more generally, how lawyers traditionally conceived what they do. The Article will next summarize trends that demonstrate how increasing numbers of lawyers are moving away from this paradigm. Third, while the existing regulatory framework under which lawyers practice largely retains traditional norms, the seeds for reconceptualizing the practice of law have been planted in amendments to and interpretations of the Model Rules. Finally, the Article will explore the degree to which regulatory changes are necessary to reflect and facilitate these developments.

\section{What Do Lawyers Do-Now And Then}

What is "traditional" and "non-traditional" in the practice of law? The Article will investigate this question by, first, exploring the "traditional" side of the analysis and then examining non-traditional trends that are filtering through the profession.

\section{What is the "Practice of Law"?}

Despite numerous attempts, no one has, to everyone's satisfaction, determined what precisely the practice of law is. ${ }^{3}$ This is not through lack of trying. The ABA sought an answer and abandoned the effort. ${ }^{4}$ Other attempts by courts and legislatures have, as noted the Restatement of the Law Governing Lawyers, been at best "vague and conclusory." Perhaps the most accurate consensus is the entirely unsatisfying and circular notion that the practice of law is what lawyers do.

While the precise definition of the practice of law as a legal matter remains elusive, what lawyers do in traditional terms is a particularly difficult question: lawyers advocate on behalf of individual clients. Indeed, the norm is perhaps more intense: lawyers provide "zealous representation," which captures a sense of tenaciousness and single-minded loyalty to clients to the exclusion of all else.

Perhaps the classic example of this understanding was delivered by English Barrister Lord Brougham in 1820:

[A]n advocate, in the discharge of this duty, knows but one person in all the world, and that person is his client. To save that client by all means and expedients, and at all hazards and costs to other persons... is his first

3. See lisa G. Lerman \& Philip G. Schrag, Ethical Problems in the Practice of Law 637-638 (2005).

4. Id. at 637 . The ABA's final report on the issue may be found at http://www.abanet.org/cpr/ model-def/recomm.pdf (last visited April 4, 2008). Representative descriptions of states' attempts to define the practice of law are as follows: D. Michael Guerin, The World is Flat... And What That Means to You, 78 Nov. WIs. LaW 2 (2005) (describing challenges in "mak[ing] any headway" on "what we believe to be the unauthorized practice of law"); Gary G. Sackett, An Analytic Approach to Defining the "Practice of Law-Utah's New Definition, 18-DeC. UTAH B.J. 12 (2005) (describing Utah's attempt at defining the "practice of law" and it's "difficult"; the effort involved "carve-outs" for "activities that may be the practice of law, but which will not be considered unauthorized practice when engaged in by non-lawyers"); Melinda J. Bentley, New Consumer Remedies for UPL, 95 ILL. B.J. 632, 633 (2007) (noting that defining the practice of law has been a "struggle" and that it "defies mechanistic formulations").

5. Restatement (Third) of the LaW Governing Lawyers $\& 4 \mathrm{cmt}$. c (2000). 
and only duty; and in performing this duty he must not regard the alarm, the torments, the destruction which he may bring upon others. ${ }^{6}$

This quote is a point of departure for numerous discussions of lawyers' duties to clients, ${ }^{7}$ and while many have disagreed with how Brougham envisions an attorneyclient relationship, the continuing centrality of his vision of practice confirms how foundational it remains. ${ }^{8}$

Nevertheless, even in Brougham's time his perspective was not universally accepted, which is perhaps why he deemed it necessary to make the statement in the first place. In one oft-cited example, Abraham Lincoln offered words of advice to lawyers: "Discourage litigation. Persuade your neighbors to compromise whenever you can. As a peacemaker the lawyer has superior opportunity of being a good man. There will still be business enough." Even earlier, Alexis de Tocqueville, in an oft-quoted observation during his travels in 1820's America, noted "[lawyers] serve as arbiters between the citizens." "Yet another famous example is the notion of "lawyer for the situation" attributed to Louis Brandeis, the essence of which rejects slavish adherence to the interests of one client, and rather suggests that lawyers should facilitate common goals among multiple parties. ${ }^{11}$

\section{The "Practice of Law": A Twenty-First Century Perspective}

Brougham's conception remains dominant in popular culture and among many in the practicing bar, yet practitioners are increasingly adhering to professional norms that Brougham would not appreciate. The following four examples offer a flavor of the related trends described in the Introduction. While these summaries are necessarily brief, they are "on the ground" examples of what lawyers are actually doing in practice and, indeed, might be familiar to many practicing lawyers in their general outlook, if not in their particulars.

The Article presents these trends from the more easily definable, such as the increasing role of lawyers as mediators, to the more conceptual, such as lawyering for the "whole person." The boundaries among these practices blur, yet this structure

6. Monroe H. Freedman, Understanding Lawyers Ethics 71 (3rd ed. 2004).

7. Joseph A. Colquitt, Evidence and Ethics, Litigating in the Shadow of the Rules, 76 FordHAM L. REv. 1641, 1666 (2007) (noting that a "wealth of scholarly discussion" begins with Brougham).

8. Anecdotally the quote remains compelling to many law students as a fair statement of the core role of a lawyer as "zealous representative."

9. Abraham Lincoln, Life and Writings of Abraham Lincoln 329 (Philip V.D. Stern, ed., 1940).

10. Carrie Menkel-Meadow, The Lawyer as Consensus Builder: Ethics for a New Practice, 70 Tenn. L. Rev. 63, 72 (2002) (quoting Alexis de Toqueville, Democracy in America 243 (J.P. Mayer \& Max Lerner eds., George Lawrence trans., 1966).

11. Clyde Spillenger, Elusive Advocate: Reconceptualizing Brandeis as People's Lawyer, 105 YALE L.J. 1445, 1502-1511 (1996). Spillenger argues that the phrase "lawyer for the situation" has multiple meanings, some of which are not as focused on lawyer as problem solver as subsequent commentators would like to believe, $i d$., but Brandeis' notion of not always acting in the exclusive interest of a client remains a plausible interpretation. 
will hopefully add coherence to the descriptions. The descriptions also include specific examples from practice.

\section{The Mediation Boom}

It is well known that alternative dispute resolution generally and mediation in particular is on the rise. Lawyers are more and more acting as mediators. ${ }^{12}$ As the Ethics 2000 Reporter herself noted in commentary on Rule $2.4,{ }^{13}$ while "[the] role of third-party neutral is not unique to lawyers... lawyers are increasingly serving in these roles." 14 This is, perhaps, the surest and most pervasive demonstration that lawyers are acting in capacities that are distinct from traditional notions of the practice of law.

The literature about mediation and lawyers' involvement in it is vast and well beyond the scope of this Article. ${ }^{15}$ Nevertheless, two points are worth noting. First, while what mediation is remains contested, ${ }^{16}$ in its most pervasive "facilitative" style $^{17}$ mediation is utterly unlike the norms of litigation in a multitude of ways: it is a voluntary process, its goal is often to promote recognition of competing perspectives, its focus is often the future and not "finding facts" about past events in order to establish liability, it embraces openness in dialogue and not narrowing "relevant facts," and it even has private meetings with mediators-something that would constitute impermissible ex parte communications if with a judge. ${ }^{18} \mathrm{~A}$ second and related point is that mediation is practiced by many different professionals, many of whom view lawyers as particularly unsuited to act as mediators because,

12. It is important to note how this section is exploring lawyers acting as mediators, not lawyers acting as advocates in mediation. The latter also raises issues about lawyers' roles and ethical rules, but while these are important issues in and of themselves and increasingly attracting scrutiny, these issues are distinct from the broader scope of this article. Loretta W. Moore, Lawyer Mediators: Meeting the Ethical Challenges, 30 FAM. L. Q. 679 (1996); Jean R. Sternlight, Lawyers' Representation of Clients in Mediation: Using Economics and Psychology to Structure Advocacy, 14 OHIO ST. J. ON DisP. RESOL. 269 (1999). For a recent ethics opinion on the issue, see ABA Formal Opinion 06-439 (2006) ("Lawyer's Obligation of Truthfulness When Representing a Client in Negotiation: Application to Caucused Mediation").

13. For a more detailed discussion of Rule 2.4 and related amendments, see infra notes 60-65.

14. aba Commission on Evaluation of the Rules of Professional Conduct, Report to the American Bar Association House of Delegates, February 2002, Reporter's Explanation of Changes to Rule 2.4.

15. One survey of the literature may be found in Robert Rubinson, Client Counseling, Mediation, and Alternative Narratives of Dispute Resolution, 10 CLINICAL L. REv. 833 (2004).

16. Kimberlee K. Kovach, Mediation: Principles and Practice 26 (3rd Ed. 2000).

17. The mediation literature on "styles" of mediation, particularly the differences between "facilitative," "evaluative," and "transformative," is immense. For two overviews of the debate, see Carrie Menkel-Meadow, When Dispute Resolution Begets Disputes of Its Own: Conflicts among Dispute Professionals, 44 UCLA L. Rev. 1871, 1887 (1997); Joseph B. Stulberg, Facilitative Versus Evaluative Mediator Orientations: Piercing the "Grid" Lock, 24 FLA. ST. U. L. REv. 985 (1997).

18. These and other differences are explored at greater length in Rubinson, supra note 16, at 846-58 (2004). 
in the words of one commentator, "lawyers' adversarial methods and mindsets are inherently inconsistent with mediation."19

Given these points, while there is some dispute as to whether being a mediator is "the practice of law," dard MDP debates - is largely beside the point. Lawyers are, in the words of the Preamble, "helping the parties to resolve a dispute or other matter." And the very title of an ABA Journal article on the subject speaks volumes: "The Lawyer Turns Peacemaker: With Mediation Emerging as the Most Popular Form of Alternative Dispute Resolution, The Quest for Common Ground Could Force Attorneys To Reinterpret Everything They Do in the Future." ${ }^{21}$ While the practice of mediation varies, lawyers are plainly involved with a facilitative process that diverges in profound ways from the norms of advocacy and litigation.

\section{Collaborative Law}

A fascinating and novel development has been the rise of "collaborative law." Collaborative law is of very recent vintage: it was developed in 1990 by a Minneapolis family law attorney named Stuart Webb. ${ }^{22}$ Nevertheless, its growth has been described as "exponential," with collaborative lawyers practicing in "virtually every state and province in the United States and Canada." ${ }^{23}$ This practice arose and continues to be centered in family law, where the adversarial process is widely viewed as intensifying family conflict to the detriment of divorcing spouses and, in particular, children. Nevertheless, collaborative law principles have arisen elsewhere, including medical malpractice cases. ${ }^{24}$

Collaborative law is, at bottom, an attempt to reject adversarial norms in favor of openness and a free sharing of information. ${ }^{25}$ It is often conceived of as referring to two related but distinct practices: an original conception, in which clients formally retain only lawyers, and a fully interdisciplinary conception-often referred to as "cooperative law"--in which clients hire a group of professionals in addition to attorneys. ${ }^{26}$ Both conceptions recognize the many intertwined aspects of matters, from the financial to the emotional, and thus a central tenet of the movement is involvement of other professionals in the process. ${ }^{27}$

19. Sternlight, supra note 12 , at 269.

20. Menkel-Meadow, supra note 10, at 90.

21. Richard C. Reuben, The Lawyer Turns Peacemaker: With Mediation Emerging as the Most Popular Form of Alternative Dispute Resolution. The Quest for Common Ground Could Force Attorneys To Reinterpret Everything They Do in the Future, 82 A.B.A. J. 54 (1996).

22. William H. Schwab, Collaborative Lawyering: A Closer Look at an Emerging Practice, 4 Pepp. Disp. Resol. L.J. 351, 354-55 (2004).

23. Gary L. Voegele, et al, Collaborative Law: A Useful Tool for the Family Law Practitioner to Promote Better Outcomes, 33 WM. MitcheLl L. Rev. 971, 975 (2007).

24. Kathleen Clark, The Use of Collaborative Law in Medical Error Situations, 19 No. 6 Health LaW. 19 (2007).

25. See Gary L. Voegele, supra note 23; Schwab, supra note 22.

26. Voegele, supra note 23 , at $976-77$.

27. Id. at 986 . 
There are a number of generally accepted characteristics of either collaborative or cooperative law. They have voluntary and transparent discovery, meetings among parties, counsel and, often, other appropriate parties such as financial planners and child psychologists, an orientation that rejects litigation as an effective option, a requirement that all attorneys involved in a matter adhere to the norms of collaborative law, and, most controversially, a retainer agreement that provides for termination of representation should the parties choose to litigate. ${ }^{28}$

The role of a collaborative lawyer differs from the role of lawyers as mediators. In mediation, lawyers undertake a distinct, non-representational role. Collaborative law involves non-adversarial and problem-solving approaches to practice. Nevertheless, collaborative law has much in common with mediation because both reject adversarial norms. Other examples follow.

\section{Lawyering for the "Whole Person"}

Some practitioners are increasingly extending their role beyond providing narrowly tailored legal expertise: they provide services to the "whole person." This perspective is sometimes called "holistic advocacy"29 but whatever its name, this notion is spreading through a remarkably diverse cross-section of the profession.

One prominent example is defending indigent criminal defendants. As one commentator has put it, " "holistic representation' . . strives to encompass the various underlying issues that often lead to clients' experiences with the criminal justice system, with the aim of addressing those circumstances and preventing future criminal involvement." ${ }^{30}$ This represents "a paradigmatic shift in defense philosophy" and "has transformed criminal defense practice by broadening the conception of what defense lawyers actually do." ${ }^{31}$ An influential organization that practices holistic advocacy in indigent criminal defense work is The Bronx Defenders, which describes its philosophy as follows:

The Bronx Defenders views clients not as "cases," but as whole people.... Our staff of attorneys, social workers, investigators, administrative support, and community organizers is committed to working with our clients, their families, and their communities to address the critical issues that circumscribe their lives. Whether defending a client's liberty; connecting

28. For a detailed overview of these characteristics of collaborative law, see Voegele, supra note 23 , at $978-86$.

29. While this term connotes a relatively specific set of practices in the academic literature, I use the term more broadly to encompass trends in which practitioners focus on the "whole client" or "situation" beyond traditional notions of zealous representation of the individual. Virtually all of the sources upon which I rely in the text are from practitioners and practitioner-oriented publications.

30. Michael Pinard, Broadening the Holistic Mindset: Incorporating Collateral Consequences and Reentry into Criminal Defense Lawyering, 31 FordHAM URB. L. J. 1067 (2004). See also Erik Luna, Punishment Theory, Holism and the Procedural Conception of Restorative Justice, 2003 UTAH L. Rev. 205, 283 (2003); David E. Rovella, The Best Defense... Rebuilding Clients' Lives to Keep Them From Coming Back, NAT'L L. J. Jan. 31, 2000, at A1 (describing indigent criminal defense attorneys who practice holistic advocacy).

31. Pinard, supra note 30 , at 1068. 
her to mental health services for the first time; encouraging individuals to engage in the civic life of their community; or preparing neighborhood youth to be the next generation of leaders, The Bronx Defenders ultimately strives to improve the lives and futures of the Bronx community as a whole. ${ }^{32}$

These practices and conceptions have influenced the larger public defender community in terms of how it approaches its clients and its work. ${ }^{33}$

This conception extends beyond the criminal defense bar. A Michigan personal injury firm describes itself in terms strikingly similar to those of The Bronx Defenders:

[W]e do not handle "cases" but rather we represent people. We believe that in addition to money, clients have other needs which must be met to permit them back into their lives.... [We] help our clients identify and obtain help for those other needs: medical, reconstructive, psychological, occupational, and personal.... [W]e form friendships with many clients that last a lifetime. ${ }^{34}$

A Georgia elder law practitioner has a practice that encompasses "geriatric care management" 35 and, among other goals, works to "minimize[] confusion and feelings of being overwhelmed while managing the care of a loved one." ${ }^{\prime 36}$ Other examples that are closely related are described below.

\section{"Lawyers for the Situation"}

Another development moves its emphasis away from a lawyer's traditional focus on zealousness on behalf of individual clients into collaborations that recall

32. http://www.bronxdefenders.org/ (last visited February 20, 2008).

33. Interview with Avis E. Buchanan, Director, Public Defender Office for the District of Columbia (February 27, 2008). One prominent example is the Georgia Justice Project, which describes itself as follows: "We are an unlikely mix of lawyers, social workers, and a landscaping company. We defend people accused of crimes and, win or lose, we stand with our clients as they rebuild their lives. We believe this is the only way to break the cycle of crime and poverty." http://www.gjp.org/ (last visited February 27, 2008). Another example is The Neighborhood Defender Service of Harlem, which provides criminal defendants with a "team defense" that "combines the tools of law and social work to provide the best services possible for our clients." http://www.ndsny.org/mission.htm (last visited February 27, 2008). For a brief overview of holistic practices in public defender work, see Robin G. Steinberg, Beyond Lawyering: How Holistic Representation Makes for Good Policy, Better Lawyers, and More Satisfied Clients, 30 N.Y.U. Rev. L. \& Soc. Change 625 (2006). See also Melissa Rothstein, Reaching through Prison Walls: Social Work in an Appellate Defender Office, 30 Apr. Champion 30 (2006).

34. The firm is Halpert, Weston, Wuori \& Sawusch. See http://www.hwwspc.com/about. shtml (last visited February 20, 2008); Steven Keeva, The Nicest Tough Firm Around, 85 A.B.A.J. 60 (1999).

35. The attorney is Victoria L. Collier, http://www.elderlawga.com/profile.html (last visited February 20, 2008). See Victoria L. Collier, Thinking of Hiring a Geriatric Care Manager? Integrating Geriatric Care Management into Your Law Practice, 200 ELDER LAW AdVISORY 1 (2007).

36. http://www.elderlawga.com/ (last visited February 21, 2008). 
Lincoln's "neighbors" and Brandeis' "situations." This is radical indeed. It subverts the zealous representation model epitomized by Brougham, the essence of which is that lawyers zealously represent a single client. ${ }^{37}$

A representative example is retold in the New York State Bar Journal. ${ }^{38} \mathrm{~A}$ litigator "at a traditional corporate law firm in Maryland" represented a "company that became aware of pollution problems at one of its facilities." The lawyer initially advised his client to "avoid[] communication with the media and its neighbors out of fear that disclosing past problems might lead to litigation," advice that the company followed for a number of years and advice with which most corporate litigators would agree. Then, upon reading a book about "seeing law differently," 39 his advice and outlook changed at a community meeting:

$[\mathrm{H}] \mathrm{e}$ apologized to the community for having advised his client to maintain a low profile. Instead, he and his environmental consultant disclosed precisely what had been done to remediate the problem and invited the community to participate in plant tours.... The community's concern and anger were dissipated by this cathartic event ... and the relationship between the company and the community was significantly improved.... Compassion, information sharing, cooperation and understanding on both sides encouraged community and commonality of purposes. There was no call for blame and no need for the waste of resources in litigation. ${ }^{40}$

While this lawyer was representing his company, his actions call into question conventional notions of "adversaries," or, needless to say, Brougham's call to disregard "the alarm, the torments, the destruction" a lawyer "may bring upon others." This attorney viewed alarm, torments, and destruction as precisely the wrong type of advocacy.

Another fascinating development in this arena is the rise of public interest "community lawyering." Community lawyering is an evolving practice that often entails working with a range of non-profit organizations and activists. Goals can vary, ranging from facilitating housing in low-income communities, assisting community entrepreneurs in attracting capital, associating with community organizations to identify service community needs, such as child-care facilities, banks, and youth centers, and engaging in lobbying and political action. ${ }^{41}$ A crucial dimension of this practice is that lawyers do not represent a client per se or presuppose a legal

37. See text accompanying notes 6-8.

38. Robert P. Borsody, A New Paradigm for Lawyers?, 74 N.Y. ST. B.J. 54 (2002). The attorney is Thomas Lynch, a partner at the Maryland firm of Miles \& Stockbridge.

39. Alan Reid, Seeing Law Differently: Views from a SPiritual path (1992).

40. Borsody, supra note 38 , at 54-55.

41. For an overview of practices and conceptions of community lawyering, see Scott L. Cummings, Community Economic Development as Progressive Politics: Toward a Grassroots Movement for Economic Justice, 54 Stan. L. Rev. 399 (2001); William H. Simon, The Community Economic Development Movement: Law, Business, and the New Social Policy (2001); Michael Diamond, Community Lawyering: Revisiting the Old Neighborhood, 32 Colum. Hum. RTs. L. Rev. 67 (2000). 
goal but play one role, indeed a subsidiary role, in the much broader enterprise of enhancing opportunity and economic well-being in impoverished communities. ${ }^{42}$

\section{Commonalities}

These trends have common themes: moving away from a narrow sense of "zealous advocacy" on behalf of individual clients; rejecting an adversarial paradigm as the sole or even primary role attorneys should undertake; approaching law practice as an enterprise that must take account of and embrace the many "nonlegal" dimensions of client representation. Moreover, other practices under other names resonate closely with these trends, such as consensus building, ${ }^{, 43}$ therapeutic jurisprudence, ${ }^{44}$ preventive law, ${ }^{45}$ among others. There are also no doubt other lawyers who might not identify themselves as "holistic" or "collaborative" or moving beyond the "paradigms of practice," yet they likely will still recognize themselves as embodying these larger trends.

\section{Regulation of The Legal Profession: Tradition and Seeds of Change}

The Model Rules, with modest exceptions, retain the traditional view of law practice. The introductory paragraphs of the Rules' Preamble represent the norms of practice from which the Rules themselves emerge:

[1] A lawyer, as a member of the legal profession, is a representative of clients, an officer of the legal system and a public citizen having special responsibility for the quality of justice.

[2] As a representative of clients, a lawyer performs various functions. As advisor, a lawyer provides a client with an informed understanding of the client's legal rights and obligations and explains their practical implications. As advocate, a lawyer zealously asserts the client's position under the rules

42. See Martha R. Mahoney et al., Social Justice: Professionals, Communities, and LaW (2003). For a particularly compelling account of the complexities of such practice, albeit in a comparative context, see Lucie E. White, To Learn and Teach: Lessons from Driefontein on Lawyering and Power, 1988 WIs. L. REv. 699 (1988).

43. Consensus building "involve[s] multiple and complex issues with more than two parties, [and] are hybrids of negotiation, case presentation, and often, legislation and rule-drafting." MenkelMeadow, supra, note 10, at 75 .

44. See Essays in Therapeutic Jurisprudence (David B. Wexler \& Bruce J. Winick eds. 1991). Therapeutic jurisprudence seeks to examine "legal arrangements with therapeutic outcomes." $I d$. at 8 . Interestingly, two commentators have drawn connections between therapeutic jurisprudence and mediation. Gary Paquin \& Linda Harvey, Therapeutic Jurisprudence, Transformative Mediation and Narrative Mediation: A Natural Connection, 3 Fla. Coastal L.J. 167 (2002). Comment [4] to Rule 2.9 of the recently revised Model Code of Judicial Conduct recognizes "therapeutic... courts"a demonstration of how the idea is spreading.

45. Robert M. Hardaway, Preventive Law: Material on a Non Adversarial legal Process xl (1997) (preventive lawyering views litigation "as a kind of failure, representing an unfortunate breakdown in the system in which parties or lawyers failed to anticipate possible conflict and take preventive measures"). 
of the adversary system. As negotiator, a lawyer seeks a result advantageous to the client but consistent with requirements of honest dealings with others. As an evaluator, a lawyer acts by examining a client's legal affairs and reporting about them to the client or to others. ${ }^{46}$

Although certainly not as radical as Brougham, there is nothing here with which Brougham would disagree. ${ }^{47}$ That said, change is in the air not only "on the ground" but at the formal level of amendments to and interpretations of the Model Rules. The following offers examples in chronological order that resonate to varying degrees with broad conceptions of non-traditional lawyering.

\section{Rule 2.1: Lawyers as Counselors about... "Moral, Economic, Social and Political Factors"}

Rule 2.1 is a call for lawyers to "exercise independent professional judgment and render candid advice." 48 It also, however, extends into territory that seems only tangentially related to "independent professional judgment" 49 by focusing on the nature of the advice itself: "In rendering advice, a lawyer may refer not only to law but to other considerations, such as moral, economic, social and political factors, that may be relevant to the client's situation." Comments [2] and [4] elaborate as follows:

Advice couched in narrow legal terms may be of little value to a client... Purely technical legal advice...can sometimes be inadequate. Matters that go beyond strictly legal questions may be in the domain of another profession.

The language goes on to identify such professions as "psychiatry, clinical psychology or social work" for family law matters and "the accounting profession" and "financial specialists" for business matters. ${ }^{50}$

While rejecting the value in most instances of "advice couched in narrow legal terms," Rule 2.1 is not clear about what the converse_- "broad legal terms"- might

46. Model Rules of Prof'l Conduct Preamble (2004).

47. To be sure, there are some statements in the Model Rules that would give Brougham, perhaps, some pause. The most likely would be Comment [1] to Rule 1.3 which, after noting that a lawyer "must... Act... with zeal in advocacy upon the client's behalf," acknowledges that a "lawyer is not bound, however, to press for every advantage that might be realized for a client" and that a lawyer is not "require[d] [to] use offensive tactics or preclude[d] from... Treating ... all persons involved in the legal process with courtesy and respect." Model Rules of Prof'L Conduct R. $1.3 \mathrm{cmt}$. [1]. In addition, as of 2005, ten states have omitted "zeal" from their Rules, although most continue to retain it. Arthur J. Lachman \& Peter R. Jarvis, Zeal in Client Representation-FAQs, Prof. Law., 2005 SympoSIUM ISSUE, 81, 83-84. Nevertheless, zeal remains a traditional cornerstone of the Model Rules' and professionals' conception of advocacy. See id.

48. Model Rules of Prof'l Conduct R. 2.1

49. Interestingly, the source of Rule 2.1 is the Model Code of Professional Responsibility Canon 5-"A Lawyer Should Exercise Independent Professional Judgment on Behalf of a Client." The Canon, and its succeeding Ethical Considerations, primarily address conflicts of interest and do not mention the nature of the advice.

50. Model Rules of Prof'L Conduct R. $2.1 \mathrm{cmt} .4$. 
mean. One implication seems to be that valuable and legitimate legal "advice" is embedded with other things that are plainly outside the traditional expertise of lawyers. A somewhat inconsistent interpretation, however, is that matters "beyond strictly legal questions" are not for lawyers but for other professionals.

In the end, Rule 2.1 is significant in the context of this Article for two reasons. First, it recognizes that the practice of law is not only about law and that "narrow legal advice" usually is an inadequate means to represent clients. Second, it legitimates the value of associating with other professionals to enhance the quality of services a lawyer provides. ${ }^{51}$

\section{Rule 5.7: The Distinction Between "Law-Related" and Legal Services}

Rule 5.7—entitled "Responsibilities Regarding Law-Related Services"—was adopted in largely its present form by the American Bar Association in 1994. ${ }^{52}$ The primary impetus behind this Rule was the rise of businesses in which lawyers owned interests and the ethical difficulties arising from these developments. ${ }^{53}$ Commentators noted that such services better served the needs of clients, although others noted that such "ancillary services" also were highly profitable ${ }^{54} \mathrm{~A}$ Comment to the Rule itself only mentions the former, ${ }^{55}$ although commentators critical of the trend cited "greed" as the primary motivation. ${ }^{56}$

51. These principles have also long been associated with David A. Binder and Paul Bergman's influential text on "client centered lawyering" and subsequent books by them with additional co-authors. David A. Binder \& Paul Bergman, Legal Interviewing and Counseling: A Client-Centered Approach (1977); David A. Binder, et al., Lawyers as Counselors: A Client-Centered Approach (2D ED. 2004) ("Lawyers as Counselors"). For example, Binder and his co-authors note that "[a]ctively encouraging clients to talk about non-legal consequences is often necessary" in the counseling process. Lawyers as Counselors, at 9. They also note how in the context of commercial transactions "the lines between the 'legal' and 'non-legal' aspects of business deals tend to blur," id. at 212 , and they devote an entire chapter to "referring clients to mental health professionals." Id. at 445-55.

52. Prior to 1994, a version of Rule 5.7, entitled "Provision of Ancillary Services," was adopted in 1991 and then was rescinded the following year. A LegisLatrve hiSTORY: THE DEVELOPMENT OF the ABA Model Rules of Professtonal Conduct, 1982-2005, 640-52 (2005). Relatively modest changes to Rule 5.7 were adopted through the Ethics 2000 process. http://www.abanet.org/cpr/e2k/ e2k-57_202.html (last visited February 28, 2008). For a detailed and excellent review of the history and debate surrounding the ancillary business phenomenon, see Block, supra note 1, at 743-44.

53. A primary concern is whether such businesses would run afoul of fee splitting prohibitions. See Loretta W. Moore, Lawyer Mediators: Meeting the Ethical Challenges, 30 FAM. L. Q. 679, 682-83 (1996). For an interesting example of one state grappling with this issue, see Maryland State Bar Association Ethics Comm. on Ethics, Op. 03-02 (2003) (given that Maryland law defines courtconnected "mediation" as not the practice of law, lawyers can create businesses with non-lawyer mediators so long as their practice is limited to court-connected mediation).

54. Block, supra note 1, at 752-54.

55. Model Rules of Prof'L Conduct R. $5.7 \mathrm{cmt}$. [9] ("[a] broad range of economic and other interests of clients may be served by lawyers' engaging in the delivery of law-related services").

56. Block, supra note 1, at 757. 
The Rule itself explains when the Rules of Professional Conduct should apply when lawyers provide law-related services. The Rule, in Comment [9], offers examples of law-related services: "providing title insurance, financial planning, accounting, trust services, real estate counseling, legislative lobbying, economic analysis, social work, psychological counseling, tax preparation, and patent, medical or environmental consulting."

The Rule's conception of law-related services is instructive because it comprises a vast array of activities, with the implicit recognition that all of these services are, at a minimum, "law-related." This is very much in the spirit of Rule 2.1. Nevertheless, the Rule seems to walk an exquisitely fine line on whether "lawrelated" services are so "related" as to be indistinguishable from legal services. On the one hand, the Rule defines "law-related services" as "not prohibited as unauthorized practice of law," ${ }^{57}$ which suggests that they are not the practice of law. On the other hand, a Comment to the Rule notes that such services can be provided "under circumstances that are not distinct from the lawyer's provision of legal services to clients." 58 This second point no doubt contemplates that "circumstances" include how attorneys present these services to clients and perhaps even the lack of physical separation between who provides them, yet confusion could only be possible (or perhaps likely) when there are exceptionally close connections between what is "law-related" and what is "law" itself.

Debates leading up to the adoption of Rule 5.7 reflect these decidedly mixed messages. James W. Jones, then at Arnold \& Porter, a firm which had created ancillary businesses, ${ }^{59}$ noted the following in 1988:

[T] he time has come for lawyers to ask themselves the question. 'What business are we in?' As the year 2000 approaches, the answer to this question may no longer be a simple one for many lawyers and the firms in which they work. Many lawyers today might find that traditional definitions of 'lawyering' no longer fit either their own activities or the demands that their clients place upon them.... [T] he range of client services and the roles often played by the firm's attorneys in client affairs might lead the attorneys to visualize themselves more accurately as 'professional problem solvers'.... ${ }^{60}$

This view was hotly contested at the time and would continue to be so. Other commentators predicted that such thinking would effectively eliminate the practice of law as a distinct enterprise, accelerate a general decline in professionalism, and

57. Model Rules of Prof'l Conduct R. 5.7(B).

58. Model Rules of Prof'l Conduct R. $5.7 \mathrm{cmt}$. [3].

59. Block, supra note 1 , at 755 .

60. James W. Jones, The Challenge of Change: The Practice of Law in the Year 2000, 41 VAND. L. REv. 683,689 (1988). The quote is cited and placed in a broader context in Block, supra note 1 , at 755 . 
subvert the traditional role that lawyers have as protectors of justice and individual rights. ${ }^{61}$

\section{Ethics 2000 and the "Third Party Neutral Amendments"}

The Ethics 2000 process and the amendments it generated ${ }^{62}$ addressed the rise of ADR and lawyers acting as "third party neutrals." The following are the "Ethics 2000 Third-Party Neutral Amendments": 63

- The Preamble to the Model Rules itself mentions specifically that "a lawyer may serve as a third-party neutral, a nonrepresentational role helping the parties to resolve a dispute or other matter." ${ }^{64}$ This is novel to the Model Rules $^{65}$ and significant as a general statement: the new wording views a "nonrepresentational role" as something that lawyers do, although the words seem to stop short of defining this role as the practice of law per se.

- Prior to Ethics 2000, Rule 1.12 governed conflicts of interest involving a "former judge or arbitrator." Rule 1.12, as amended, adds "mediator or other third-party neutral" to the title, and the subsequent text of the rule, for the most part, folds in "mediator or other third-party neutral" as well as a "judge" or "arbitrator" into its provisions. ${ }^{66}$

- Ethics 2000 added an entirely new Rule-Rule 2.4-which is consistent with the "non-representational" amendments included in the Preamble. Rule 2.4(a), like the Preamble, embodies an important amplification of the "non-representational" role referenced in the Preamble: "Service as a thirdparty neutral may include service as an arbitrator, a mediator or in such other capacity as will enable the lawyer to assist the parties to resolve the matter" (emphasis added). This seems, incrementally, to move into the notion that

61. Block collects these and other criticisms. Id. at 756-57.

62. For sources on the Ethics 2000 process and the amendments that resulted from it, see ABA, Center for Professional Responsibility, Ethics 2000 Commission, Report on the Model Rules of Professional Conduct, http://www.abanet.org/cpr/e2k/e2k-report_home.html (last visited February 25, 2008) ("Ethics 2000 Report"); ABA, Summary of House of Delegates Action on Ethics 2000 Commission Report, http://www.abanet.org/cpr/e2k/e2k-summary_2002.html (last visited February 25,2008 ).

63. For a somewhat more detailed discussion of these amendments, see Menkel-Meadow, supra note 10 , at $84-87$.

64. Model Rules of Prof'l Conduct, Preamble, Paragraph [3].

65. Ethics 2000 deleted Rule 2.2 which, while referring to lawyers acting as "intermediaries," contemplated lawyers undertaking common representation, that is, representing multiple clients and conflicts that might arise as a result. The text of the deleted Rule 2.2 is available in the Ethics 2000 Commission Report, http://www.abanet.org/cpr/e2k/e2k-rule22.html (last visited February 25, 2008).

66. For a redlined version of the prior and Ethics 2000 version of Rule 1.12, see Ethics 2000 Commission Report, http://www.abanet.org/cpr/e2k/e2k-112_202.html (last visited February 25, 2008). 
the lawyer qua lawyer acts as a third-party neutral, although, once again, this is implicit in the language.

- Comment [5] to Rule 2.1 states that "when a matter is likely to involve litigation, it may be necessary under Rule 1.4 to inform the client of forms of dispute resolution that might constitute reasonable alternatives to litigation." This amendment generated and continues to generate a lively debate about whether it should mandate counseling about the availability of $\mathrm{ADR}^{67}$ : its "may be necessary" language is a remarkable melding of the mandatory and the discretionary. Nevertheless, this new Rule demonstrates a movement toward recognizing that engaging in non-adversarial processes is a subject about which lawyers should counsel clients.

These amendments collectively represent an incremental recognition in the Model Rules that the traditional paradigm of zealous, individual advocacy does not fully address what lawyers are doing. The implications of these amendments is that lawyers can and do play a "non-representational" role-something of an oxymoron under conventional notions of practice. These amendments-particularly Rule 2.4-also represent something perhaps less obvious but just as important: such nontraditional practices are still subject to regulation under the ethical rules. There is thus both a recognition that lawyers increasingly see themselves in new ways and that these new ways-although unconventional under traditional norms-can and should be regulated.

\section{The ABA and Collaborative Law}

A recent ABA Ethics Committee Opinion found collaborative law practice can be undertaken in accordance with ethical rules. ${ }^{68}$ As with the Ethics 2000 Third-Party Neutral Amendments, this Opinion is interesting not only for the specific question it answers-whether a collaborative practice is ethical-but also for how it analyzes one type of non-traditional practice under Rules that are, as noted above, traditional in character.

The Opinion confronted the most controversial aspect of collaborative law: given that the process contemplates a "contractual obligation to withdraw" if it fails, a collaborative lawyer's services cannot extend to subsequent litigation. ${ }^{69}$ The Opinion views an agreement between a client and a collaborative lawyer as "a limited scope representation" permissible under Rule $1.2(\mathrm{c}),{ }^{70}$ which provides that "a lawyer may limit the scope of representation if the limitation is reasonable under the circumstances."

67. Andrew Schepard, Kramer vs. Kramer Revisited: A Comment on the Miller Commission Report and the Obligation of Divorce Lawyers for Parents to Discuss Alternative Dispute Resolution with Their Clients, 27 PACE L. REv. 677 (2007).

68. ABA Comm. on Ethics and Prof'l Responsibility, Formal Op. 07-447 (2007). Other state bar associations reached the same conclusion with only one exception. Id. at 2 .

69. Id. at 3.

70. Id. at 4 . 
The Opinion rejects an argument that this arrangement renders it impossible for a lawyer to provide "competent and diligent representation" and thus creates a non-consentable conflict of interest under Rule $1.7(b)(1) .^{71}$ To the contrary, the Opinion found that the client has merely agreed to limit her lawyer's role and may pursue all avenues, including litigation, if succeeding events warrant it. There is irony here, though, given that collaborative lawyering is inherently inconsistent with the Model Rules, at least in the sense that its practices wildly veer from norms embodied in the Rules. This is not to say that the Opinion's reasoning is wrong: to the contrary, in terms of its analysis, it seems entirely correct. Rather, it appears that the premises underlying the Model Rules do not, in and of themselves, foreclose non-traditional practices; the Model Rules are flexible enough to be interpreted consistently with them.

\section{Is there a Need for Regulatory Action?}

Many of the practices summarized in this Article have already been the subject of detailed scholarly analyses of the ethical quandaries they raise, including those arising from mediation, ${ }^{72}$ collaborative law,${ }^{73}$ community lawyering,${ }^{74}$ and holistic lawyering. ${ }^{75}$ These analyses make detailed observations and proposals about these specific processes and trends that need not be repeated here.

Without delving into such specificity, it is worth noting that the Model Rulesa set of Rules informed by, as noted above, traditional notions of practice ${ }^{76}$-have flexibility to accommodate, at a broad level, new trends in what it means to practice law. There is reason to believe that whatever the ultimate resolution of debates

71. Id. This argument is actually somewhat puzzling on its own terms because it is not entirely clear why, even if this were the case, a client's participation in a collaborative law process would be impaired by another client, a "third person" or the lawyer's "personal interest" so as to constitute a concurrent conflict of interest under Rule 1.7(a)(2).

72. There is a particularly extensive literature on the subject of mediation and legal ethics. Carrie Menkel-Meadow has, in particular, been a vocal and influential commentator in this regard. See Menkel-Meadow, supra note 10; Carrie Menkel-Meadow, Ethics in ADR: The Many "Cs" of Professional Responsibility and Dispute Resolution, 28 FordHAM URB. L.J. 979 (2001). See also Loretta W. Moore, Lawyer Mediators: Meeting the Ethical Challenges, 30 FAM. L. Q. 679 (1996).

73. Christopher M. Fairman, A Proposed Model Rule for Collaborative Law, 21 Oню ST. J. on DisP. Resol. 73 (2005); Larry R. Spain, Collaborative Law: A Critical Reflection on Whether a Collaborative Orientation Can Be Ethically Incorporated into the Practice of Law, 56 BAYLOR L. Rev. 141 (2004); John Lande, Possibilities for Collaborative Law: Ethics and Practice of Lawyer Disqualification and Process Control in a New Model of Lawyering, 64 OHIо ST. L.J. 1315 (2003).

74. Shauna I. Marshall, Mission Impossible?: Ethical Community Lawyering, 7 Clinical L. REv. 147 (2000).

75. Stacy L. Brustin, Legal Services Provision Through Multidisciplinary PracticeEncouraging Holistic Advocacy while Protecting Ethical Interests, 73 U. CoLo. L. REv. 787 (2002); J. Michael Norwood \& Alan Paterson, Problem-Solving in a Multidisciplinary Environment? Must Ethics Get in the Way of Holistic Services, 9 CliniCaL L. REv. 337 (2002).

76. See supra text accompanying note 47. 
surrounding, for example, $\mathrm{MDP}^{77}$ and mandatory counseling about $\mathrm{ADR},{ }^{78}$ existing rules may, in some instances, accommodate new practices. At the same time, existing trends at a more formal level-preeminently the adoption of Rules 2.4 and 5.7-suggest that amendments facilitating new trends will continue as new practices become more pervasive and acceptable to larger segments of the profession. ${ }^{79}$

The analysis presented in this Article suggests that the profession will interpret its current regulations, when it can, in line with emerging practices, and that the profession will, albeit incrementally and when necessary, amend the Rules to permit them. The regulatory framework of the profession either has or will, sooner or later, reflect current practices, especially in a profession that continues a long and proud tradition of self-regulation. ${ }^{80}$

In this regard, it is worth noting a striking example of how longstanding professional norms, heretofore resistant to change, are finally subject to reform. The case method-the core law school pedagogy since Christopher Columbus Langdell became the Dean of Harvard Law School in the $1870 \mathrm{~s}^{81}$ - is in the process of substantial revision by, once again, Harvard Law School. Harvard is introducing a new required course on problem-solving-a change reflecting, in the words of the current Harvard Dean Elena Kagan, that "the world of law has changed" and that law school must reflect "changes in what our students will do and what they need to know." 82 These changes have been influential and will likely be a model that other law schools will follow. ${ }^{83}$ While the Harvard changes reflect calls for reform in legal education that became particularly visible with the issuance of the MacCrate Report in 1992, ${ }^{84}$ one crucial aspect of legal education that has resisted change for over 130 years has, at long last, begun to change. ${ }^{85}$ Moreover, as with the Model Rules discussed above, existing regulations governing legal education,

77. See supra text accompanying note 1.

78. See supra text accompanying note 67.

79. For one example of a new proposed Model Rule to facilitate collaborative law, see Fairman, supra note 73.

80. For a statement of self-regulation and its justifications, see Model Rules of Prof'l ConDUCT, Preamble, cmts. [10]-[12].

81. Edward Rubin, What's Wrong With Langdell's Method and What To Do About It, 60 VAND. L. REv. 609, 617 (2007).

82. Jonathan D. Glater, Harvard Law Decides to Steep Students in 21 st-Century Issues, N.Y. Times, Oct. 7, 2006.

83. See also Jonathan D. Glater, Training Law Students for Real-Life Careers, N.Y. Times, Oct. 31, 2007. Glater notes that the Harvard changes have "galvanized reflection at many law schools."

84. aBA, Legal Education and Professional Development-an educational Continuum, Report of the Task force on Law Schools and the Profession: Narrowing the GAP (1992). Very recent studies have further amplified the message of the MacCrate Report. Roy Stuckey and Others, Best Practices for Legal Education (2007); William M. Sullivan et al., Educating Lawyers: Preparation for the Profession of Law (2007).

85. This is not to suggest that these changes necessarily reflect the trends described in this Article, although, plainly, "problem-solving" has connections with the shifting nature of the understanding of what needs to be addressed in solving client's problems. 
such as the ABA Accreditation Standards, ${ }^{86}$ embody traditional norms yet do not stand in the way of changes that reflect new norms and practices. ${ }^{87}$

\section{Conclusion}

While the norms of the legal profession remain very much intact, changes are in the air. These changes are spreading even as the profession continues to segment and specialize. Increasing numbers of lawyers view practice couched in "narrow legal terms" ${ }^{188}$ as no longer capturing the nature of the professional services they provide.

The Model Rules represent traditional norms yet, inevitably, must reflect the realities of the profession they seek to regulate. While there is necessarily a lag before realities catch up with formalized norms, the process is inevitable. And, in this case, inevitability is a good thing as the profession continues to reinvent what it means to practice law.

86. aba Section on Legal Education and Admissions to the Bar, 2007-2008 StanDARDS FOR APPROVAL OF LAW SCHOols, available at http://www.abanet.org/legaled/standards/stan dards.html (last visited February 29, 2008).

87. In a comparable development, the National Conference of Bar Examiners-a body that undertakes another practice resistant to reform-added a "Multistate Performance Test" in 1997. The MPT seeks to assess applicants' ability to do some of the things that lawyers actually do in practice: examine case files and investigate facts. http://www.ncbex.org/multistate-tests/mpt/ (last visited February 29, 2008).

88. See text accompanying note 50 . 